\title{
kellundite 8, un nuevo cemento
}

(aux etats-unis: un nouveau ciment)

editorial

de sJournal de la Construction de la Suisse Romandex, año 31, núm. 24, diciembre 1956, păg. 1480

Una flrma americana acaba de lanzar al mercado un nuevo cemento-Kellundite 8-, empleado en los hornos de arco de las fundiciones de acero o de cobre. El revestimiento interno de estos hornos, ejecutado con dicho cemento, presenta una mayor resistencia al calor y al desgaste. Se ha demostrado que el óxido de aluminio resiste mejor las altas temperaturas y los ataques de las escorias que los cementos ordinarios empleados en los hornos para aleaciones férreas y no férreas.

Este revestimiento de horno pesará $500-1.000$ libras $(226,8-453,6 \mathrm{~kg})$. El Kellundite también puede utilizarse para la reparación de revestimientos ya existentes. 